\title{
KARAKTERISASI TRICHODERMA HARZIANUM ASAL LAHAN GAMBUT SEBAGAI AGENS ANTAGONIS TERHADAP PENYEBAB PENYAKIT BUSUK PANGKAL BATANG SAWIT SECARA IN VITRO
}

\author{
CHARACTERIZATION OF TRICHODERMA HARZIANUM ORIGIN OF PEATSOIL AS \\ ANTAGONIST AGENTS OF PALM OIL STEM ROT IN VITRO
}

Elsy Nandung, Iman Suswanto dan Tris Haris Ramadhan

Program Studi Agroteknologi Fakultas Pertanian Universitas Tanjungpura Jln. Prof. Dr. Hadari Nawawi, Pontianak, 78124, Indonesia.

\begin{abstract}
ABSTRAK
T. harzianum merupakan agen antagonis yang digunakan untuk pengendalian hayati. Penelitian ini bertujuan mengetahui keragaman cendawan dari beberapa jenis vegetasi di lahan gambut, mengetahui kemampuan daya hambat dan sifat-sifat lain $T$. harzianum penentuan sifat yang dapat digunakan sebagai penciri $T$. harzianum sebagai agens pengendali busuk pangkal batang, dan kemampuan mendegradasi kitin sebagai salah satu komponen dinding sel Ganoderma spp.. Pengujian ini dilakukan melalui hasil isolasi T. harzianum dari beberapa areal, inkubasi menggunakan media PDA kemudian dilakukan pencirian berdasarkan uji antagonis, uji pertumbuhan, morfologi dan mekanisme penghambatan, uji kitinase dilakukan dengan menginkubasi cendawan T. harzianum pada media kolodial kitin diamati zona bening setiap hari. Keragaman cendawan dari berbagai wilayah relatif sama. Agen pengendali Ganoderma spp. seperti busuk pangkal batang banyak ditemukan pada wilayah yang ditumbuhi cabai dan hutan belukar. Pencirian T. harzianum terbaik berdasarkan tingginya daya hambat, kerapatan spora dan mekanisme penghambatan. Mekanisme penghambatan bersifat hiperparasit mampu menekan pertumbuhan Ganoderma spp. melalui degradasi kitin.
\end{abstract}

Kata kunci : Busuk pangkal batang, gambut, pencirian T. harzianum, sawit

\section{ABSTRACT}

T. harzianum an agent antagonist that is used for biological control. This study aims to determine the diversity of fungi of several types of vegetation in peatland, determine the ability of inhibitation and other properties of T. harzianum. Determination of the properties could be used for identifier T. harzianum as a control agent of Ganoderma spp. stem rot. The test is performed through isolated T. harzianum from some areas, incubation using PDA media then conducted based on the test antagonist characterization, test the growth, morphology and the mechanism of inhibition, chitinase test performed kitin on colloidal media.The ability hiperparasit as inhibitory mechanism against pathogens. The diversity of fungi from various regions are relatively the same. Agents Ganoderma spp. such as stem rot is found in many areas covered by the chili and woods. Characterization of T. harzianum The best by the high power resistor, spore density and inhibitory mechanisms. Hiperparasit inhibition mechanism is able to suppress the growth of Ganoderma spp. through the degradation of chitin.

Keyword: Palm peat, Stem rot, Trichoderma spp. characterization. 


\section{PENDAHULUAN}

Perkebunan sawit memiliki peranan penting sebagai sumber ekonomi masyarakat. Luas areal sawit sampai tahun 2014 mencapai 10,9 juta hektar dengan produksi CPO 31,5 juta ton/tahun atau setara dengan 88,2 juta ton/tahun tandan buah segar. Saat ini Indonesia tercatat sebagai pengekspor CPO terbesar dunia dengan sumbangan devisa 4,14 miliar dolar (Harahap, 2014).

Salah satu kendala produksi sawit berupa penyakit busuk pangkal batang yang disebabkan Ganoderma boninense. Kerugian akibat penyakit berkisar antara 50-100\% (Semangun, 1999). Patogen termasuk penyakit tular tanah (soil borne disease) memiliki kemampuan bertahan dalam tanah, sisa tanaman hutan dan tanaman perkebunan lain (Nurhayati, 2013). Trichoderma harzianum telah banyak dilaporkan sebagai agens pengendali terhadap penyakit busuk pangkal batang. Cendawan ini mempunyai kemampuan berkembangbiak cepat, penekanan patogen menggunakan kombinasi mekanisme penghambatan sehingga efektif menekan pertumbuhan patogen (Priwiratama $d k k, 2014$ ).

Tujuan penelitian a) mengetahui keragaman cendawan dari beberapa jenis vegetasi di lahan gambut, b) mengetahui kemampuan daya hambat dan sifat-sifat lain Trichoderma harzianum, c) Penentuan sifat yang dapat digunakan sebagai penciri Trichoderma harzianum sebagai agens pengendali $G$. boninense, dan d) kemampuan mendegradasi kitin sebagai salah satu komponen dinding sel Ganoderma spp.

\section{BAHAN DAN METODE}

Penelitian dilakukan dengan mengambil tanah asal kebun cabai, sawit, jagung, nenas dan lahan hutan pada lahan gambut di Kecamatan Rasau Jaya dan Laboratorium Penyakit Tanaman, Fakulutas Pertanian Universitas Tanjungpura, Pontianak dari bulan Juni - November 2014.

\section{Isolasi dan Perbanyakan Jamur $G$. boninense.}

Tubuh buah jamur dibersihkan dari tanah dan kontaminan lainnya dengan air leding. Selanjutnya dipotong bagian tengah ukuran $0,5 \mathrm{~cm}^{2}$, ditanam pada media PDA dalam cawan petri dengan jarum ose

Inkubasi selama 7 hari setelah inokulasi (HSI), miselium yang muncul ditumbuhkan kembali pada PDA media miring dalam tabung reaksi. Isolat diinkubasi pada suhu kamar sampai memenuhi permukaan agar dan disimpan sebagai bahan uji. (Harahap, 2014).

\section{Keragaman Cendawan}

Cendawan diisolasi dari beberapa wilayah di desa Rasau Jaya yang terdiri dari wilayah tanaman cabe, tanaman sawit, tanaman jagung, tanaman nenas, hutan belukar yang berasal dari lahan gambut. Masingmasing wilayah diambil 5 titik sampel. Sampel tanah diambil sebanyak 50 gram dicampur secara merata. Tanah dari semua titik pengambilan dicampur merata lalu diambil sebanyak 10 gram dan dimasukkan ke dalam $90 \mathrm{ml}$ air steril dalam tabung reaksi. Kemudian suspensi tanah di shaker secara horizontal selama 15 menit, diencerkan sampai konsentrasi suspensi $10^{4}$.

Suspensi tanah pada konsentrasi $10^{4}$ diinokulasi sebanyak $1 \mathrm{ml}$ pada media PDA dalam cawan petri. Selanjutnya diinkubasi selama 2-3 hari, sambil diamati semua cendawan yang muncul dan Trichoderma harzianum diisolasi ke media miring. Kegiatan ini diulang sebanyak 3 kali.

\section{Uji Antagonis dan Pencirian T.harzianum}

Uji antagonis Trichoderma harzianum terhadap G.boninense dilakukan dengan metode dual kultur menurut (Muksin $d k k$, 2013). Selanjutnya diinkubasi selama 3 HSI, kemudian diukur diameter koloni G.boninense masing-masing yang berdampingan dengan setiap Trichoderma harzianum. Pencirian dengan melakukan uji pertumbuhan Trichoderma harzianum ditanam pada media 
yang telah disiapkan pada bagian tengahtengah petri kemudian pada hari kedua dilakukan pengukuran diameter koloni menggunakan penggaris, proporsi koloni bersporulasi dilakukan pengukuran pada hari kelima dengan melihat perubahan warna pada Trichoderma harzianum, jumlah kerapatan spora dihitung pada hari ketujuh setelah inkubasi.

\section{Uji Kitinase}

Dilakukan dengan cara menumbuhkan Trichoderma harzianum Pada media koloidal kitin dan pengamatan perubahan zona bening masing-masing isolat mekanisme penghambatan. Perubahan zona bening diukur menggunakan penggaris (Dewi, 2008)

\section{Analisis Data}

Daya hambat Trichoderma harzianum terhadap G.boninense dapat dihitung dengan rumus menurut (Muksin $d k k, 2013$ )

$$
\mathbf{P}=\frac{r 1-r 2}{r 1} X 100 \%
$$

Keterangan:

P : Persentase pertumbuhan cendawan Trichoderma harzianum r1: Jari-jari cendawan Trichoderma mendekati cendawan uji

r2: Jari-jari Trichoderma harzianum menjauhi cendawan uji

Diperoleh data dengan menggunakan nilai uji korelasi.

\section{HASIL DAN PEMBAHASAN}

\section{Keragaman Cendawan}

Hasil pengamatan keragaman jenis cendawan dari beberapa vegetasi di lahan gambut pada Tabel 1 menunjukkan bahwa jenis cendawan kurang beragam dan terdapat kesamaan dari berbagai asal vegetasi. Jenis cendawan yang ditemukan terdiri atas $T$. harzianum, Monilia sp., Penicillium sp., Aspergillus niger dan Fusarium spp. Cendawan ini termasuk kelompok saprofit yaitu cendawan yang mampu memperoleh energi dari sisa-sisa tanaman. Hasil yang sama juga dijumpai pada pengamatan kepadatan populasi cendawan (Tabel 1) menunjukkan kepadatan yang relatif sama. Kepadatan populasi cendawan berkisar antara 24-27 coloni forming unit (CFU).

Tabel 1. Keragaman dan Kepadatan Koloni Cendawan dari Beberapa Vegetasi Di Lahan Gambut

\begin{tabular}{|c|c|c|c|c|}
\hline No & Jenis Vegetasi & $\begin{array}{c}\text { Jenis } \\
\text { Cendawan }\end{array}$ & $\begin{array}{l}\text { Kepadatan } \\
\text { koloni (cfu) }\end{array}$ & Total koloni (cfu) \\
\hline \multirow[t]{4}{*}{1} & Cabe & Penicillium sp. & 5 & 24 \\
\hline & & Aspergillus niger & 12 & \\
\hline & & T. harzianum & 7 & \\
\hline & & Fusarium sp. & 3 & \\
\hline \multirow[t]{3}{*}{2} & Sawit & Penicillium sp. & 6 & 26 \\
\hline & & Aspergillus niger & 16 & \\
\hline & & T. harzianum & 5 & \\
\hline \multirow[t]{3}{*}{3} & Jagung & Penicillium sp. & 14 & 26,4 \\
\hline & & Aspergillus flavus & 6 & \\
\hline & & T. harzianum & 3 & \\
\hline \multirow[t]{3}{*}{4} & Nenas & Penicillium sp. & 16 & 25,4 \\
\hline & & Aspergillus niger & 4 & \\
\hline & & T. harzianum & 4 & \\
\hline \multirow[t]{4}{*}{5} & Hutan & T. harzianum & 11 & 26,6 \\
\hline & & Monilia sp. & 15 & \\
\hline & & Penicillium sp. & 5 & \\
\hline & & Aspergillus niger & 16 & \\
\hline
\end{tabular}


Hal ini berarti berbagai agroekosistem yang diamati memiliki kesamaan sehingga hanya mendukung jenis cendawan tersebut. Diduga jenis vegetasi yang berbeda menghasilkan bahan organik serupa yang dapat dimanfaatkan sebagai sumber energi bagi kelima jenis cendawan tersebut. Hal ini sesuai dengan pendapat (Handayani, 2002) menyatakan kandungan bahan organik yang tinggi dalam tanah dapat mendorong pertumbuhan cendawan secara cepat. Jumlah dan aktivitas cendawan di dalam tanah dibatasi oleh masukan $\mathrm{C}$ yang berasal dari produksi bahan organik yang berasal dari sisa-sisa tanaman dalam tanah tergantung pada ketersediaan karbon.

Diduga wilayah areal cabe dan hutan belukar banyak terdapat bahan organik yang dapat mendukung pertumbuhan cendawan. $T$. harzianum sebagai agens hayati patogen. $T$. harzianum merupakan cendawan ascomycetes, memiliki aktivitas antifungal yang banyak ditemukan di tanah hutan dan maupun tanah pertanian atau subtrat berkayu (Kurnia et al., 2014).

\section{Uji Antagonis dan Pencirian T. harzianum}

Hasil pengamatan daya hambat $T$. Harzianum terhadap G. boninense pada Tabel 2 menunjukkan bahwa terdapat perbedaan kemampuan antar isolat $T$. harzianum. Kelompok isolat yang memiliki potensi agens pengendali patogen ditunjukkan dengan daya penghambatan di atas nilai rata-rata atau lebih dari $46 \%$. Terdapat delapan isolat $T$. harzianum sebagai calon agens pengendali ternyata sebagian besar diperoleh dari kebun cabai dan hutan masing-masing 3 isolat. Selain itu, sebagian besar isolat memperlihatkan kemampuan hiperparasit sebagai mekanisme penghambatan terhadap patogen. proporsi keseragaman sporulasi koloni ternyata memiliki keeratan hubungan yang rendah dengan kemampuan isolat sebagai agens pengendali, keeratan hubungan antara kemampuan penghambatan dengan pertumbuhan miselium $\left(\mathrm{r}^{2}=0,30\right)$, zone sporulasi $\left(r^{2}=0,16\right)$. Sedangkan pertumbuhan kerapatan konidia memiliki keeratan hubungan sebesar $\left(r^{2}=0,57\right)$ keeratan hubungan juga ditunjukkan oleh mekanisme penghambatan bersifat hiperparasit. Diduga kerapatan spora dan mekanisme hiperparasit merupakan pencirian T. harzianum yang bersifat unggul. Faktor penting yang menentukan aktivitas mikroorganisme antagonis untuk mengendalikkan patogen adalah memiliki kerapatan spora yang tinggi sehingga mampu berkompetisi (Djaenuddin, 2011).

\section{Uji Kitinase}

Hasil pengamatan uji kitinase $T$. harzianum pada Tabel 3 menunjukkan terdapat perbedaan kemampuan mendegradasi kitin antar isolat dari beragam mekanisme penghambatan. Kemampuan mendegradasi kitin ditandai dengan terbentuknya zona bening. Sifat yang terlihat pada Gambar 1 ketiga isolat yang diuji menunjukkan bahwa isolat 2.3.2 yang termasuk dalam kelompok dengan mekanisme penghambatan hiperparasit memiliki kemampuan tertinggi mendegradasi kitin sebesar $5,5 \mathrm{~cm}$. Hal ini berarti mekanisme hiperparasit dapat digunakan sebagai dasar dalam pemilihan agens pengendali Ganoderma spp. Diduga mekanisme penghambatan hiperparasit berkaitan dengan kemampuan cendawan untuk merusak dinding sel patogen yang disusun kitin.

Kitin merupakan komponen utama penyusun dinding sel dan Selulosa adalah polimer tidak bercabang dari glukosa yang dihubungkan melalui ikatan 1,4 $\beta$-glikosida jamur kelas Ascomycetes, Basidiomycetes, 
Deuteromycetes, dan Citridiomycetes (Kristianasari, 2004). Hifa Ganoderma spp. termasuk dalam famili Basidiomycetes disusun oleh selulosa dan kitin. Cendawan mengeluarkan kitinase untuk menguraikan menjadi karbon dan nitrogen (Kristianasari, 2004). Sementara T. harzianum mampu merusak dinding sel Ganoderma spp. dengan menghasilkan kitinase sehingga cendawan dapat memanfaatkan kitin dan substrat lain dari patogen sebagai sumber karbon. T. harzianum memproduksi metabolit seperti asam sitrat, etanol, dan berbagai enzim seperti urease, selulase, glukanase, dan kitinase (Azzamy, 2015). Mekanisme penghambatan $T$. harzianum terjadi pada hari ke 3 HSI setelah pertemuan antara koloni patogen dan agens antagonis.

Tabel 2. Beberapa Sifat T. harzianum sebagai Agens Pengendali Penyebab Penyakit Busuk Pangkal Batang Sawit yang Diperoleh dari Beberapa Jenis Vegetasi Di Lahan Gambut

\begin{tabular}{|c|c|c|c|c|c|c|c|}
\hline No & $\begin{array}{l}\text { Nomor } \\
\text { Isolat }\end{array}$ & $\begin{array}{c}\text { Daya } \\
\text { hambat (\%) } \\
\text { 3 HSI }\end{array}$ & $\begin{array}{c}\text { Diamete } \\
\text { r koloni } \\
2 \text { HSI } \\
(\mathrm{cm}) \\
\end{array}$ & 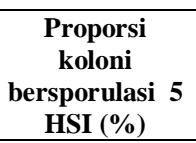 & $\begin{array}{c}\text { Kerapatan } \\
\text { Spora } 7 \\
\text { HSI }(1 \text { ml) }\end{array}$ & $\begin{array}{c}\text { Warna Koloni setelah } \\
\text { Bersporulasi }\end{array}$ & $\begin{array}{c}\text { Mekanisme } \\
\text { Penghambatan }\end{array}$ \\
\hline 1 & 2.3 .2 & 50.00 & 6.25 & 95 & $13 \times 10^{6}$ & Hijau & Hiperparasit \\
\hline 2 & 1.1 .4 & 48.88 & 6.00 & 50 & $7,5 \times 10^{6}$ & Hijau & Antibiosis \\
\hline 3 & 1.3 .3 & 48.88 & 5.00 & 90 & $6 \times 10^{6}$ & Hijau & Hiperparasit \\
\hline 4 & 1.3 .2 & 46.15 & 5.60 & 90 & $7,5 \times 10^{6}$ & Putih hijau muda & Antibiosis \\
\hline 5 & 4.3 .1 & 46.15 & 5.70 & 80 & $7 \times 10^{6}$ & Hijau muda & Hiperparasit \\
\hline 6 & 5.1 .3 & 46.15 & 5.75 & 85 & $7 \times 10^{6}$ & Hijau & Hiperparasit \\
\hline 7 & 5.2 .2 & 46.15 & 5.75 & 40 & $7,5 \times 10^{6}$ & Hijau muda & Hiperparasit \\
\hline 8 & 5.3 .1 & 46.15 & 5.25 & 80 & $7 \times 10^{6}$ & Hijau tua & Hiperparasit \\
\hline 9 & 1.1 .2 & 43.42 & 3.75 & 70 & $6 \times 10^{6}$ & Hijau muda & Hiperparasit \\
\hline 10 & 2.1 .1 & 43.42 & 3.95 & 85 & $6 \times 10^{6}$ & Putih hijau muda & Hiperparasit \\
\hline 11 & 2.2 .1 & 43.42 & 4.10 & 90 & $10 \times 10^{6}$ & hijau muda & Antibiosis \\
\hline 12 & 5.1 .5 & 43.42 & 5.30 & 80 & $7 \times 10^{6}$ & $\begin{array}{l}\text { Putih hijau } \\
\text { kekuningan }\end{array}$ & Hiperparasit \\
\hline 13 & 1.3 .1 & 42.85 & 5.04 & 90 & $7,5 \times 10^{6}$ & hijau muda & Antibiosis \\
\hline 14 & 2.2 .2 & 42.85 & 3.95 & 75 & $12 \times 10^{6}$ & Hijau & Antibiosis \\
\hline 15 & 3.1 .1 & 42.85 & 3.40 & 80 & $7,5 \times 10^{6}$ & Putih hijau muda & Kompetisi \\
\hline 16 & 3.2 .1 & 42.85 & 6.05 & 70 & $10 \times 10^{6}$ & hijau muda & Hiperparasit \\
\hline 17 & 5.2 .3 & 42.85 & 5.70 & 90 & $7,5 \times 10^{6}$ & Hijau & Antibiosis \\
\hline 18 & 2.3 .1 & 42.50 & 4.10 & 80 & $13 \times 10^{6}$ & Hijau & Hiperparasit \\
\hline 19 & 5.1 .1 & 42.50 & 5.80 & 90 & $12 \times 10^{6}$ & $\begin{array}{l}\text { Putih hijau } \\
\text { kekuningan }\end{array}$ & Antibiosis \\
\hline 20 & 1.1 .3 & 37.11 & 5.00 & 80 & $12 \times 10^{6}$ & Hijau & Hiperparasit \\
\hline 21 & 3.3 .1 & 37.11 & 5.50 & 95 & $12 \times 10^{6}$ & Hijau & Hiperparasit \\
\hline 22 & 4.1 .1 & 37.11 & 6.25 & 90 & $7,5 \times 10^{6}$ & Hijau muda & Hiperparasit \\
\hline 23 & 4.2 .1 & 37.11 & 6.00 & 70 & $10 \times 10^{6}$ & Hijau & Kompetisi \\
\hline 24 & 4.3 .2 & 37.11 & 5.70 & 90 & $7 \times 10^{6}$ & Hijau muda & Hiperparasit \\
\hline 25 & 4.3 .3 & 35.71 & 4.75 & 90 & $10 \times 10^{6}$ & Hijau & Hiperparasit \\
\hline 26 & 5.2 .1 & 35.71 & 6.05 & 90 & $12 \times 10^{6}$ & Hijau & Hiperparasit \\
\hline 27 & 5.3 .2 & 35.71 & 5.60 & 75 & $8 \times 10^{6}$ & Hijau & Kompetisi \\
\hline 28 & 1.1 .1 & 35.71 & 3.40 & 30 & $3 \times 10^{6}$ & Hijau & Kompetisi \\
\hline 29 & 5.1 .2 & 33.33 & 5.50 & 80 & $13 \times 10^{6}$ & Hijau & Hiperparasit \\
\hline 30 & 5.1 .4 & 33.33 & 5.90 & 85 & $13 \times 10^{6}$ & Hijau & Kompetisi \\
\hline 31 & 5.3 .1 & 33.33 & 5.70 & 80 & $7 \times 10^{6}$ & Hijau muda & Kompetisi \\
\hline \multicolumn{2}{|c|}{ Rata-rata } & 41,28 & 5,15 & 79,51 & $8,8 \times 10^{6}$ & & \\
\hline \multicolumn{2}{|c|}{$\begin{array}{l}\text { Stansdar } \\
\text { deviasi }\end{array}$} & 4,98 & 0,87 & 15,13 & $2 \times 10^{6}$ & & \\
\hline
\end{tabular}

Keterangan : urutan angka pertama, kedua dan ketiga berturut-turut: wilayah asal isolat, ulangan isolasi dan nomor isolat 
Tabel 3. Uji Kitinase berdasarkan Mekanisme Penghambatan Secara Antibiosis, Hiperparasit dan Kompetisi

\begin{tabular}{|c|c|c|c|c|}
\hline \multirow{2}{*}{ Nomor Isolat } & \multirow{2}{*}{$\begin{array}{c}\text { Mekanisme } \\
\text { penghambatan }\end{array}$} & \multicolumn{3}{|c|}{ Diameter zone bening $(\mathrm{cm})$} \\
\hline & & 3 HSI & $4 \mathrm{HSI}$ & $5 \mathrm{HSI}$ \\
\hline 2.3 .2 & Hiperparasit & 4.3 & 4.8 & 5.5 \\
\hline 1.1.4 & Antibiosis & 3.7 & 4.2 & 5 \\
\hline $\begin{array}{l}1.1 .4 \\
3.1 .1\end{array}$ & Kompetisi & 3.5 & 4.1 & 5.3 \\
\hline Rata-rata & & 3,83 & 4,36 & 5,26 \\
\hline Standar deviasi & & 0,41 & 0,37 & 0,25 \\
\hline
\end{tabular}

Pengamatan mekanisme penghambatan agens antagonis $G$. boninense dilakukan ke 1 HSI, disebabkan oleh adanya pertemuan antara kedua koloni tersebut. Dalamkeadaan normal pertumbuhan koloni T.harzanum akan memenuhi Petri pada hari ke 3 HSI sedangkan G.boninense membutuhkan waktu 7 HSI. Pada hari ke 7 HSI dapat diketahui mekanisme penghambatan. Penghambatan mekanisme hiperparasit terjadinya overlap, mekanisme antibiosis terjadinya pembentukan zona bening, sedangkan mekanisme kompetisi terjadi penebalan miselim pada pertemuan kedua koloni. Mekanisme penghambatan Trichoderma spp. dapat terjadi melalui hiperparasitparasit (memarasit miselium cendawan lain dengan menembus dinding sel dan masuk kedalam sel untuk mengambil zat makanan dari dalam sel sehingga cendawan akan mati). Menghasilkan antibiotik seperti alametichin, paracelsin, trichotoxin yang dapat menghancurkan sel cendawan melalui pengrusakan terhadap permeabilitas membran sel, dan enzim chitinase, laminarinase yang dapat menyebabkan lisis dinding sel. Mempunyai kemampuan berkompetisi memperebutkan tempat hidup dan sumber makanan, mempunyai kemampuan melakukan interfensi hifa (Ismail, 2011).

\section{SIMPULAN}

1. Keragaman cendawan Penecillium spp., Aspergillus niger, T. harzianum, Fusarium spp., Aspergillus flavus, Monolia spp., dari berbagai wilayah relatif sama berdasarkan jenis cendawan, kepadatan koloni dan total koloni.

2. Calon agens pengendalian Ganoderma spp. banyak ditemukan pada wilayah yang ditumbuhi cabai dan hutan belukar.

3. Pencirian T. harzianum terbaik berdasarkan tingginya daya hambat, kerapatan spora dan mekanisme hiperparasit.

4. Mekanisme penghambatan hiperparasit mampu menekan pertumbuhan Ganoderma spp. melalui degradasi kitin. 


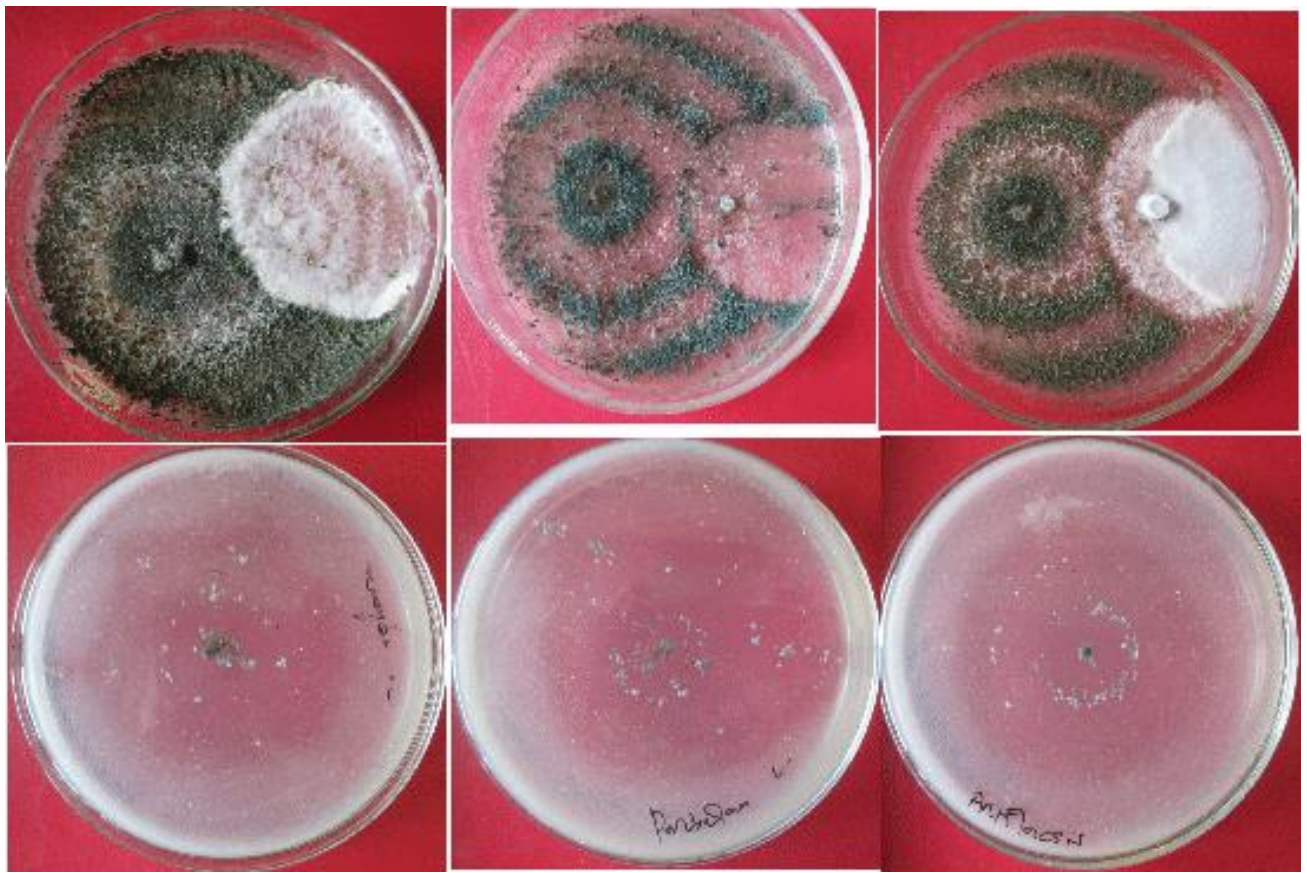

Gambar 1. Beberapa Mekanimse Isolat T. harzianum dalam Menekan G.boninense. dari Kiri ke Kanan Mekanimse Penghambatan dan Kemampuan Degradasi Kitin dari Isolat 3.1.1, 2.3.2 dan 1.1.4 Berturut Kompetisi, Hiperparasit dan Antibiosis

\section{DAFTAR PUSTAKA}

Azzamy, 2015. Trichoderma spp. Sebagai Antifungal Pengendali Penyakit Cendawan. Artikel Hama dan Penyakit. Jakarta. Mitalom.com

Djaenuddin N, 2011. Bioteknologi penyakit layu fusarium( Fusarium oxysforum). Prosiding Seminar dan pertemuan XXI PEI. Komda Sulsel. Makasar.

Harahap Y., 2014. Produksi Industri Kelapa Sawit 2014. Pusat Penelitian Kelapa Sawit. Medan Sumatera Utara, Indonesia.

Ismail, 2007. Potensi Agen Hayati Trichoderma spp. Sebagai Agen Pengendalian Hayati. Balai Pengkajian Teknologi Pertanian. Sulawesi Utara.

Kristianasari D, 2004. Pemanfaatan Daun Ilalang (imperata cylindrica) Sebagai Campuran Media Tanaman Pada Pertumbuhan Jamur Ling zhi (Ganoderma lucidum). Skripsi. Fakultas
Matematika dan Ilmu Pengetahuan Alam Universitas Diponegoro. Semarang. Tidak dipublikasi.

Kurnia, AR. \& M. Widyaiswara, 2014. Membuat Biakan Trichoderma spp. Dengan Beras. Balai Besar Pelatihan Binung. Banjar Masin.

Muksin R, Rosmini \& Johanis, 2013. Uji Antagonisme Trichoderma spp. Terhadap Jamur Patogen Alternaria porri Penyebab Penyakit Bercak Ungu Pada Bawang Merah Secara In Vitro. Fakulutas Pertanian Untad. Sulawesi Tengah. Agrotekbis 1(2): 140-144.

Nurhayati, 2013.Tanah dan Perkembangan Patogen Tular Tanah. Prosiding Seminar Nasional. Palembang.

Priwiratama H, Susanto, 2014. Pengendalian Penyakit Busuk Pangkal Batang Secara Kultur Teknis. Pusat Penelitian Kelapa Sawit. Medan. 